\title{
Supply Chain Relationship, Technological Innovation and Firm Performance in Sport Goods Industry*
}

\author{
Jun Zhao \\ School of Business Administration \\ Zhongnan University of Economics and Law \\ Wuhan, China
}

\author{
Xiaoyan Liu \\ School of Business Administration \\ Jianghan University \\ Wuhan, China
}

\begin{abstract}
Supply chain management of China's sports goods industry is becoming the focus of practitioners and researchers. Taking the panel data of domestic sports goods listed companies from 2008 to 2017 as a research sample; this study investigates the relationship between supply chain relationship, enterprise technological innovation and enterprise performance in the sports industry. Results indicate that supplier relationship has an impediment to enterprise performance; however, there are no significant and positive effects between customer relationship and enterprise performance in sports industry. Both supplier relationship and customer relationship have significant hindrance effects on enterprise technological innovation. This paper specifically explored the mediating role of enterprise technological innovation in such relationship showed that enterprise technological innovation has a negative mediating effect between supplier relationship and enterprise performance. The paper enriches current research on the supply chain in sports industry, and provides significant managerial implications for sports supply chain practitioners and managers, attempt to shift their vision from the enterprises should always maintain close cooperative relationships with upstream and downstream partners of the supply chain to tailor-made supply chain cooperation strategy, and, the paper suggests that the expectation of cooperative technological innovation should be weakened and independent innovation should be strengthened.
\end{abstract}

Keywords-supply chain relationship; technological innovation; firm performance; sport goods industry

\section{INTRODUCTION}

Competition in the supply chain is becoming the major form of modern market competition, emphasis on management of supply chain has become general consensus theory and practice community, the Sport goods industry is no exception. The theoretical exploration, supply chain studies on sport goods industry still in its infancy, which focused on risk control, process optimization or new technologies such as cloud services, Big Data technology and other aspects of the application. However, as a complex system, in-depth interpretation of the mechanism of supply chain management theory, such as supply chain relationships, supply chain responsibility, supply chain integration, electronic applications and other aspects of firm performance upgrade path is urgent. At the same time, the sport goods

*Project: This study was supported for State Program of Social Sciences of China (Project No.:18G038) industry has the characteristics of high market concentration, obvious separation of brand and manufacturing, and brings practical difficulties to supply chain management.

The upstream and downstream relationship of the supply chain is becoming the key to the success of modern supply chains. From upstream and downstream supply chain firms by source, supply chain relationships can be divided into supplier relationships and customer relationships, the relationship between these two types of impact on firms Performance are subject to the attention of scholars. Many scholars believe that, in many areas, has a close relationship can bring to enhance supply chain management and supply chain synergies to the performance of the firm.

At the same time, cooperative technology innovation is an essential and critical component of firm technology innovation, and may even be the primary source of firm technology innovation, relying on the good relationship between firms and partners (upstream and downstream of supply chain). Therefore, in sport goods industry, whether cooperative technological innovation driven by the same supply chain relationships and a positive impact on firm performance is our first two issues to be examined.

\section{THEORETICAL BACKGROUND AND HYPOTHESES DEVELOPMENT}

\section{A. Supply Chain Relationship and Firm Performance}

In recent years, competition between firms has changed into competition among supply chains, and supply chains have become an essential feature of business organizations, such as strategic alliances, strategic partnerships, business associations, strategic network, strategic supply chain and other new forms of supply chain, between particular organizations are essentially between fair trade and vertical integration to build relationships. The supply chain is a complex network of all relevant suppliers, manufacturers and customers. The upstream and downstream firms in the organization constitute the basic supply and purchase relationship. This relationship may be based solely on transactions or on a deeper level of strategy. Consider these, all of which are called "supply chain relationships." Suppliers upstream of the supply chain and customers downstream of the supply chain are firms' stakeholders, and these related firms can have a significant impact on business 
operations. Scholars have also continuously tested whether supply chain relationships affect and how firms' performance is affected. Most scholars have pointed out that controlling supply chain relationships can give firms a competitive advantage, if the relationship between the firm and the upstream and downstream firms in the supply chain is maintaining and operating to a reasonable level can bring certain operational "synergy" to the firm and improve the performance of the firm and the entire supply chain. In summary, there are the following assumptions:

H1: In the sporting goods industry, firms have a good supply chain relationship, which positively affects their performance.

H1a: In the sporting goods industry, a good relationship between firms and suppliers positively affects their performance;

H1b: In the sporting goods industry, a good relationship between firms and customers positively affects their performance.

\section{B. The Mediating Role of Firm Cooperation Technology Innovation}

The importance of technological innovation in firms is receiving widespread attention. Firm Technology Innovation not be overlooked is that technological innovation in the supply chain, namely the firm and supply chain upstream and downstream firms through close cooperation and integration of resources bring technological improvements and innovations. Therefore, from the customer a sense, suppliers upstream of the supply chain and downstream customers are important drivers of technological innovation. Later, some scholars have verified this view, and believe that the participation and support of suppliers and customers in firm technology innovation can positively and significantly affect the (innovative) performance of firms. In this discussion, there is an obvious premise, namely firms need to maintain good relationships with the upstream and downstream of the supply chain. Therefore, combined with the previous discussion of supply chain relationships, there are reasons to believe that firm technology innovation may play an important intermediary role in the path of supply chain relationship to firm Performance. Therefore the hypotheses as follows:
H2: In the sport goods industry, the firms' cooperation technological innovation has a mediating effect on the relationship between the cooperation relationships and their performance.

H2a: Sports goods firms keep good relationship with suppliers and positively influence their performance through technological innovation;

H2b: Sports goods firms keep good relationship with customers and positively influence their performance through technological innovation.

Combined with the discussion on the relationship between supply chain relationship, technological innovation and firm performance, the conceptual model of this paper as shown in the "Fig. 1":

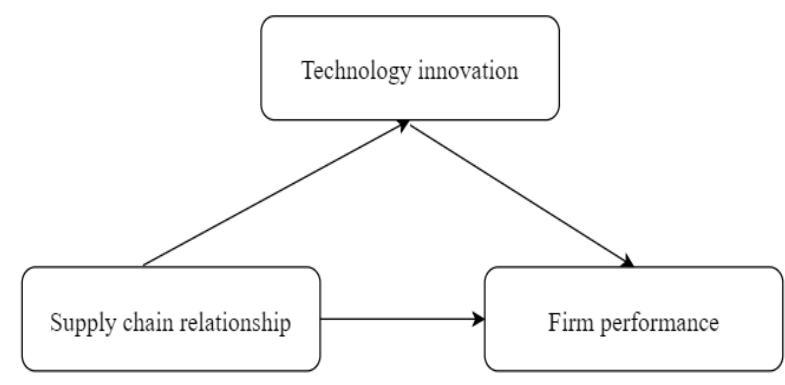

Fig. 1. Conceptual model.

\section{RESEARCH DESIGN}

\section{A. Sample Selection and Data Source}

We choose firms listed in 2008 and before, that is, have a listing time of ten years or more. Secondly, this study does not restrict the listing location, that is, the listing places include the two stock markets of Shenzhen Stock Exchange and Hong Kong Stock Exchange. In the end, nine sporting goods listed firms (Li Ning, Anta, 361 International, Xtep International, Baosheng International, Jialinjie, Shenzhou International, Xinlong Industrial, and China Trends) were selected for panel observation for ten consecutive years.

\section{B. Variable Definition}

The definition of variables is shown in "Table I".

TABLE I. OBSERVATION VARIABLES, DEFINITIONS AND DESCRIPTIVE STATISTICS

\begin{tabular}{|c|c|c|c|c|c|c|c|}
\hline variable & & \begin{tabular}{|c|} 
variable definition \\
\end{tabular} & Minimum & Maximum & Mean & S.D & Variance \\
\hline \multirow{3}{*}{$\begin{array}{c}\text { Firm } \\
\text { Performance }\end{array}$} & LnsalesR & $\begin{array}{l}\text { The natural logarithm of the ratio of current year's } \\
\text { sales to last year's sales }\end{array}$ & -0.2194 & 0.5479 & 0.0559 & 0.1212 & 0.0150 \\
\hline & ROTA & $\begin{array}{l}\text { Return on total assets equals annual net profit / } \\
\text { divided by total assets }\end{array}$ & -0.3224 & 0.2309 & 0.0822 & 0.0912 & 0.0080 \\
\hline & ROE & $\begin{array}{l}\text { Return on equity is equal to the net profit of } \\
\text { shareholders divided by the equity of shareholders }\end{array}$ & -0.7800 & 1.2262 & 0.2686 & 0.4064 & 0.1650 \\
\hline \multirow{3}{*}{$\begin{array}{l}\text { Supplier } \\
\text { relationship }\end{array}$} & SupplierFive & $\begin{array}{l}\text { The sum of the payment amount of the top five } \\
\text { suppliers accounts for the proportion of the } \\
\text { company's sales }\end{array}$ & 0.0970 & 0.9800 & 0.3251 & 0.2035 & 0.0410 \\
\hline & SupplierCon & $\begin{array}{l}\text { The square of the sum of the payment ratios of the } \\
\text { top five suppliers }\end{array}$ & 0.0100 & 0.5100 & 0.1227 & 0.1117 & 0.0120 \\
\hline & SupplierFirst & $\begin{array}{l}\text { The amount of payment to the largest supplier } \\
\text { accounted for the company's sales }\end{array}$ & 0.0094 & 0.9604 & 0.1466 & 0.2145 & 0.0460 \\
\hline
\end{tabular}




\begin{tabular}{|c|c|c|c|c|c|c|c|}
\hline variable & & variable definition & Minimum & Maximum & Mean & S.D & Variance \\
\hline \multirow{3}{*}{$\begin{array}{l}\text { Customer } \\
\text { relationship }\end{array}$} & $\begin{array}{l}\text { CustomerFiv } \\
\text { e }\end{array}$ & $\begin{array}{l}\text { The sum of the purchase amount of the top five } \\
\text { customers accounts for the proportion of the } \\
\text { company's sales }\end{array}$ & 0.1360 & 0.8573 & 0.3696 & 0.2265 & 0.0510 \\
\hline & $\begin{array}{l}\text { CustomerCo } \\
\mathrm{n}\end{array}$ & $\begin{array}{l}\text { The square of the sum of the purchase ratios of the } \\
\text { top five customers }\end{array}$ & 0.0130 & 0.4307 & 0.1325 & 0.1052 & 0.0110 \\
\hline & $\begin{array}{l}\text { CustomerFir } \\
\text { st }\end{array}$ & $\begin{array}{l}\text { The proportion of the largest customer purchase } \\
\text { amount to the company's sales }\end{array}$ & 0.0185 & 0.7350 & 0.1873 & 0.2285 & 0.0520 \\
\hline \multirow{3}{*}{$\begin{array}{l}\text { Technological } \\
\text { Innovation }\end{array}$} & Lnpat & $\begin{array}{l}\text { The indicator for measuring the number of } \\
\text { technological innovations in firms }\end{array}$ & 0.0000 & 3.7136 & 1.2332 & 0.9363 & 0.8770 \\
\hline & Lnlnn & $\begin{array}{l}\text { The number of domestic invention patent } \\
\text { applications add } 1 \text {, then the natural logarithm is } \\
\text { taken }\end{array}$ & 0.0000 & 3.2189 & 0.7476 & 0.8041 & 0.6470 \\
\hline & RDSTR & R\&D intensity & 0.0001 & 0.1261 & 0.0238 & 0.0225 & 0.0010 \\
\hline \multirow{6}{*}{$\begin{array}{c}\text { Control } \\
\text { variables }\end{array}$} & Lnsize & $\begin{array}{l}\text { The size of the enterprise, the natural logarithm of } \\
\text { the total assets of the enterprise over the years }\end{array}$ & 1.0131 & 2.8093 & 1.8718 & 0.3737 & 0.1400 \\
\hline & GDP & Domestic annual GDP growth rate & 0.0670 & 0.1064 & 0.0827 & 0.0135 & 0.0000 \\
\hline & AI & $\begin{array}{l}\text { Asset concentration, expressed as total assets } \\
\text { divided by sales revenue }\end{array}$ & 0.5560 & 8.9612 & 1.6352 & 1.5777 & 2.4890 \\
\hline & Taxrate & Effective tax rate, & -0.0507 & 10.4532 & 0.3695 & 1.0917 & 1.1918 \\
\hline & Lnage & $\begin{array}{l}\text { Established time, the natural logarithm of the } \\
\text { company's establishment period }\end{array}$ & 0.0000 & 2.7726 & 1.2552 & 0.5056 & 0.2560 \\
\hline & YR & $\begin{array}{l}\text { Set annual virtual control variables based on } 2008 \\
\text { to control annual effects }\end{array}$ & - & - & - & - & - \\
\hline
\end{tabular}

TABLE II. DESCRIPTIVE Statistics AfTER THE LATENT VARIABLES ARE MANIFESTED

\begin{tabular}{|c|l|l|l|l|l|}
\hline Variables & \multicolumn{1}{|c|}{ Minimum } & Maximum & Mean & \multicolumn{1}{|c|}{ S.D } & \multicolumn{1}{|c|}{ Variance } \\
\hline Firm Performance $(\boldsymbol{F P})$ & -0.5512 & 0.7035 & 0.1754 & 0.2389 \\
\hline Supplier Relationship $($ SR) & 0.0635 & 0.7450 & 0.2239 & 0.1550 \\
\hline Customer Relationship $(\boldsymbol{C R})$ & 0.0794 & 0.5940 & 0.2510 & 0.0240 \\
\hline Technological Innovation $(\boldsymbol{T I})$ & 0.0000 & 2.3036 & 0.6682 & 0.1631 \\
\hline
\end{tabular}

\section{MODEL \& HYPOTHESIS TESTING}

Firstly, the following econometric model is set to empirically test the impact of supply chain relationship on enterprise performance:

$$
\begin{aligned}
& F P_{i, t}=a_{0}+a_{1} S R_{i, t}+a_{2} \text { Controls }_{i, t}+a_{3} Y R_{t}+\varepsilon_{i, t} \\
& F P_{i, t}=a_{0}+a_{1} \text { CR }_{i, t}+a_{2} \text { Controls }_{i, t}+a_{3} Y R_{t}+\varepsilon_{i, t}
\end{aligned}
$$

Model (1) represents the regression equation of supplier relationship to firm performance, and model (2) represents the regression equation of customer relationship to firm performance is the company and $t$ is the year. The firm performance (FP) is the firm performance, including the two indicators of the total return on assets ROTA and ROE defined above. The explanatory variables SR and CR are supplier relationship and customer relationship respectively, which are measured by supplier concentration and customer concentration. Specific indicators are defined in the previous section; Controls is a set of control variables, including enterprise size Lnsize, establishment time length Lnage, domestic GDP growth rate GDP, asset concentration AI, and the effective tax rate of the company is Taxrate. In addition, the model also controls the annual effect YR. $\varepsilon$ is the random interference term of the model.

Secondly, in order to explore the role of firm technology innovation in supply chain relations and firm performance in the sporting goods industry, the mediation effect analysis method summarized by Wen Zhonglin et al. to use technological innovation as a mediator variable, respectively, supplier relationship and The impact of customer relationships on technological innovation, the specific model is set as follows:

$$
\begin{gathered}
T I_{i, t}=\beta_{0}+\beta_{1} S R_{i, t}+\beta_{2} \text { Controls }_{i, t}+\beta_{3} Y R_{t}+\varepsilon_{i, t} \\
T I_{i, t}=\gamma_{0}+\gamma_{1} C R_{i, t}+\gamma_{2} \text { Controls }_{i, t}+\gamma_{3} Y R_{t}+\varepsilon_{i, t}
\end{gathered}
$$

Finally, technical innovation is also included in the regression equation as an explanatory variable to measure the impact on firm performance.

$$
\begin{aligned}
& F P_{i, t}=\delta_{0}+\delta_{1} S R_{i, t}+\delta_{2} T I_{i, t}+\delta_{3} \text { Controls }_{i, t}+\delta_{4} Y R_{t}+\varepsilon_{i, t} \\
& F P_{i, t}=\mu_{0}+\mu_{1} C R_{i, t}+\delta_{2} T I_{i, t}+\mu_{3} \text { Controls }_{i, t}+\mu_{4} Y R_{t}+\varepsilon_{i, t}
\end{aligned}
$$

In the above model, TI represents the technological innovation of the intermediary variable firm; similarly, $\varepsilon$ is also the random interference term corresponding to each model. 


\section{EMPIRICAL RESULTS AND TEST}

Descriptive statistics were mainly calculated by SPSS software, while regression analysis was conducted by $\mathrm{R}$ (3.5.1) software.

\section{A. Descriptive Statistics}

"Table II" describes the statistical characteristics of the main observed variables. Since the latent variables are used in the study to measure some constructs, it is first necessary to convert the latent variables into explicit variables, which can avoid measurement errors.

\section{B. The Main Regression Results}

According to the previous basic model, to ensure the validity of the data, the fixed effect model and the random effect are judged by the equation (1) and equation (2), and use Hausman Test to test and find that both equations are suitable for random model. The results of the model analysis show that supplier relationships have a significant negative effect on firms Performance ( $\beta=-0.6934715 * * *)$, that is, the more firms rely on large suppliers, the worse the performance of the firm. However, the improvement of customer relationships the performance of firms' performance was not significant $(\beta=0.2700748)$, and the study refused to assume $\mathrm{H} 1 \mathrm{a}$ and $\mathrm{H} 1 \mathrm{~b}$.

In the relationship between supply chain relationships and technological innovation, the results show (see "Table III") that both supplier and customer relationships have a significant hindrance to the technological innovation of the firm $(\beta=-1.249082 * * *$ and $\beta=-1.088322 * * *)$.

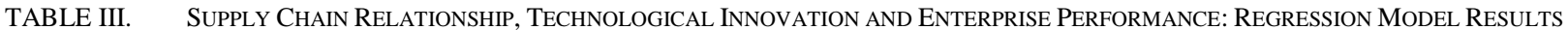

\begin{tabular}{|c|c|c|c|c|c|c|c|}
\hline & \multicolumn{4}{|c|}{ Dependent variables (base) } & \multirow{2}{*}{\multicolumn{2}{|c|}{$\begin{array}{c}\text { Dependent variables (mediating) } \\
\text { EP }\end{array}$}} \\
\hline & & \multicolumn{2}{|r|}{ FP } & \multicolumn{2}{|c|}{ TI } & & \\
\hline & & (1) & (2) & (3) & (4) & (5) & (6) \\
\hline \multirow{2}{*}{$\begin{array}{l}\text { Independent } \\
\text { variables }\end{array}$} & $S R$ & $-0.6934715 * * *$ & - & $-1.249082^{* * * *}$ & - & $-0.855537 * * *$ & - \\
\hline & $C R$ & - & 0.2700748 & - & $-1.088322^{* * *}$ & - & $0.3794053^{*}$ \\
\hline $\begin{array}{c}\text { Mediating } \\
\text { variables }\end{array}$ & $T I$ & - & - & - & - & $-0.129748^{*}$ & 0.1004578 \\
\hline \multirow{5}{*}{$\begin{array}{c}\text { Control } \\
\text { variables }\end{array}$} & Lnsize & $0.2893649 * * *$ & 0.1142734 & $0.421273 * * *$ & $0.344688 * *$ & $0.344024 * * *$ & 0.0796468 \\
\hline & GDP & 3.0159265 & 2.1414096 & $-7.079150 * *$ & -2.841763 & 2.097423 & 2.4268868 \\
\hline & $A I$ & $-0.0418313^{* *}$ & -0.0216387 & $-0.106563^{* * * *}$ & $-0.068489 * *$ & $-0.055658 * *$ & -0.0147584 \\
\hline & Taxrate & -0.0085958 & -0.0092651 & -0.046898 & $-0.054513 *$ & -0.014681 & -0.0037888 \\
\hline & Lnage & $-0.1003380^{*}$ & -0.0833634 & $0.607027 * * *$ & $0.869798 * * *$ & -0.021578 & $-0.1707413^{*}$ \\
\hline Control & $Y R$ & Yes & Yes & Yes & Yes & Yes & Yes \\
\hline \multicolumn{2}{|c|}{ (Intercept) } & -0.26268 & -0.1398160 & 0.174269 & -0.428324 & -0.240069 & -0.0967875 \\
\hline \multicolumn{2}{|c|}{ Total Sum of Squares } & 5.079 & 5.079 & 28.321 & 28.321 & 5.079 & 5.079 \\
\hline \multicolumn{2}{|c|}{ Residual Sum of Squares } & 3.8249 & 4.5657 & 7.8033 & 8.9259 & 3.6935 & 4.4756 \\
\hline \multicolumn{2}{|c|}{ Adj. R-Squared } & 0.19248 & 0.036083 & 0.70455 & 0.66205 & 0.21071 & 0.043577 \\
\hline \multicolumn{2}{|c|}{$F$-statistic } & $\begin{array}{l}4.53576 \text { on } 6 \text { and } \\
83 \text { DF, p-value: } \\
0.0005\end{array}$ & $\begin{array}{l}1.55527 \text { on } 6 \text { and } 83 \\
\text { DF, p-value: } 0.1706\end{array}$ & $\begin{array}{l}36.3731 \text { on } 6 \text { and } 83 \\
\text { DF,p-value: } 0.0000\end{array}$ & $\begin{array}{l}30.0589 \text { on } 6 \text { and } 83 \\
\text { DF,p-value: } 0.0000\end{array}$ & $\begin{array}{l}4.39419 \text { on } 7 \text { and } 82 \\
\text { DF, p-value: } 0.0003\end{array}$ & $\begin{array}{l}1.57929 \text { on } 7 \text { and } \\
82 \text { DF, p-value: } \\
0.15316\end{array}$ \\
\hline \multicolumn{2}{|c|}{ Hausman Test } & $\begin{array}{l}\text { chisq }=0.459, \mathrm{df} \\
=5, \mathrm{p} \text {-value }= \\
0.9935\end{array}$ & $=\begin{array}{l}\text { chisq }=0.17399, \mathrm{df} \\
=5, \quad \text { p-value }= \\
0.9994\end{array}$ & $\begin{array}{l}\text { chisq }=0.22367, \mathrm{df} \\
=5, \quad \text { p-value }= \\
0.9988\end{array}$ & $\begin{array}{l}\text { chisq }=0.55695, \mathrm{df} \\
=5, \quad \text {-value }= \\
0.9899\end{array}$ & $\begin{array}{l}\text { chisq }=0.48884, \mathrm{df}= \\
6, \mathrm{p} \text {-value }=0.998\end{array}$ & $\begin{array}{l}\text { chisq }=0.31439, \\
\text { df }=6, \text { p-value }= \\
0.9994\end{array}$ \\
\hline
\end{tabular}

\section{Mediating Effect of Technological Innovation}

The most widely used mediating effect test method is the causal step method proposed by Baron and Kenny (1986). Although it is controversial, it is still the most widely used method in the current academic field. Causality test method steps as follows: when the explanatory variables are supplier relationships, the impact on firms performance due to significant negative variables $(-0.6934715 * * *)$, meet the conditions of the first step; the second step is to test the intervening variable of technological innovation The impact of the variable firm performance is also negatively significant $(-1.249082 * * *)$; the third step is that supplier relationship and technological innovation also act as explanatory variables to influence firms Performance, and find that supplier relationship has a significant negative impact on firms Performance. (-0.855537***), technological innovation also has a significant negative impact on the performance of listed Sport goods $(-0.129748 *)$, that is, technological innovation is a partial negative intermediary role, the mediation effect is $(\mathrm{a} b / \mathrm{c}=-0.2337)$.

At the same time, the relationship between listed firms and customers remains good and does not significantly affect the performance of firms $(0.2700748)$, not to mention, on the contrary, this close relationship will seriously hinder the technological innovation of firms $(-1.088322 * * *)$, when customers When relationship and technological innovation simultaneously act as explanatory variables to influence firms Performance, it is found that customer relationship has never changed significantly to significant $\left(0.3794053^{*}\right)$, while technological innovation has become irrelevant $(0.1004578)$. This does not mean that technological innovation is in sports use.

As an intermediary role in the product industry, it is more certain that the intimate relationship between listed Sport 
goods firms and major customers will bring big drawbacks, that is, firms must carry out specialized innovation and special investment for customers, while ignoring their own innovative plans. Even in the short-term, the firm will be obscured by the interests of customers. Therefore, the study refuses to assume $\mathrm{H} 2 \mathrm{a}$ and $\mathrm{H} 2 \mathrm{~b}$.

\section{CONCLUSION}

From the results of data analysis, the impact of supply chain relationships of listed companies in the domestic sport goods industry on firm performance is unclear. First, the impact of the relationship between listed sport goods firms and suppliers on firms performance is significantly negative, revealing the current situation of the sport goods industry and other industries, that is, if the firm is too dependent on important suppliers (such as the top five or the first A supplier) will have a hindrance to firms performance. In general, there are two reasons for relying on important suppliers: First, they are forced to rely on; because there are not many alternative supplier companies available for listed firms in the sport goods market; second, because these firms are at sport goods suppliers. It may also be an important customer. This is also known from the sample selection. Most of the listed sport goods firms are well-known Chinese brands and have a high market share. As customers, they are subject to special investment by suppliers, which may restrict the supplier's supplier conversion behavior. Ultimately, the disappearance of this power of choice and bargaining power will increase the risk of supply chain disruption and inventory risks and hinder the improvement of firms' performance. Secondly, maintaining a good relationship between these sporting goods listed firms and major customers can improve the performance of the company, but it is not significant. According to the sample types selected by the Institute, important customers such as Anta and $\mathrm{Li}$ Ning are authorized dealers of the company. These dealers have high bargaining power and channel management capabilities, and listed firms cannot replace major purchasing customers at any time.

In addition to the importance of supply chain relationships to firm's performance, firm's technological innovation is playing an increasingly important role in the increasingly fierce market competition. To ensure that the industry is at the forefront of the industry, it is bound to need to increase R\&D investment.

At the same time, technological innovation plays a part of the negative intermediary role in the path of supplier relationship affecting firm's performance, that is, the transformation of supplier relationship into technology innovation has a significant negative impact on firm performance. Technological innovation on the path of customer relationships affecting firm's performance does not assume an intermediary role. Although some of the mediating role of technological innovation is drives, it is contrary to our assumptions.

The theoretical contribution of this research is mainly that in the current sports research field, few scholars have integrated supplier relations and customer relationships into supply chain relations and studied the differences between them on firm's performance. This paper first made domestic sports goods industry. This attempt; Secondly, this study attempts to use the related theories in economics to explore the relationship between supply chain relations, technological innovation and firm's performance in the sporting goods industry, and to some extent reveal the sporting goods industry. There are some differences with other industries and corresponding explanations.

\section{REFERENCES}

[1] Zhou L, Chong A Y L, Ngai E W T. Supply chain management in the era of the internet of things $[\mathrm{J}]$. International Journal of Production Economics, 2015, 159: 1-3

[2] Lumineau F, Henderson J E. The influence of relational experience and contractual governance on the negotiation strategy in buyersupplier disputes [J]. Journal of Operations Management, 2012, 30(5): 382-395.

[3] Hult G T M, Ketchen D J, Arrfelt M. Strategic supply chain management: Improving performance through a culture of competitiveness and knowledge development [J]. Strategic management journal, 2007, 28(10): 1035-1052.

[4] Freeman L C, Roeder D, Mulholland R R. Centrality in social networks: II. Experimental results [J]. Social networks, 1979, 2(2): 119-141.

[5] Johnston D A, McCutcheon D M, Stuart F I, et al. Effects of supplier trust on performance of cooperative supplier relationships [J]. Journal of operations Management, 2004, 22(1): 23-38.

[6] Huo B, Qi Y, Wang Z, et al. The impact of supply chain integration on firms Performance: The moderating role of competitive strategy [J]. Supply Chain Management: An International Journal, 2014, 19(4): 369-384.

[7] Titman S. The effect of capital structure on a firm's liquidation decision [J]. Journal of financial economics, 1984, 13(1): 137-151.

[8] Arranz N, De Arroyabe J C F. Effect of formal contracts, relational norms and trust on performance of joint research and development projects [J]. British Journal of Management, 2012, 23(4): 575-588

[9] Carey S, Lawson B, Krause D R. Social capital configuration, legal bonds and performance in buyer-supplier relationships [J]. Journal of Operations Management, 2011, 29(4): 277-288.

[10] Goffin K, Lemke F, Szwejczewski M. An exploratory study of 'close'supplier-manufacturer relationships [J]. Journal of operations management, 2006, 24(2): 189-209. 